\section{A National Council for Mental Hygiene.}

A GENERAI meeting will be held at 5 o'clock on A Thursday, May 4, in the rooms of the Royal Society of Medicine, Wimpole Street, in order to decide on the constitution, officers, etc., of the new National Council for Mental Hygiene. The provisional committee consists of Sir Courtauld Thomson (chairman), Sir Norman Moore, Sir Charles Sherrington, Sir John Goodwin, Sir George Newman, Sir Walter Fletcher, Dr. C. H. Bond, Dr. Bedford Pierce, Prof. George Robertson, Dr. C. S. Myers, Dr. G. Ainsworth, Dr. Helen Boyle, Dr. Edwin Bramwell, Dr. Farquhar Buzzard, Sir Maurice Craig, Lord Dawson of Penn, Sir Horatio Donkin, Prof. Elliot Smith, Dr. Edwin Goodall, Dr. Henry Head, Dr. Crichton Miller, Sir Frederick Mott, Dr. W. H. R. Rivers, Sir Humphry Rolleston, Dr. T. A. Ross, Dr. Tredgold, and Dr. W. Worth.

A letter, signed by Sir Courtauld Thomson, appeared in the Times of March 29 which describes the purposes for which the new Council is being established. It will co-ordinate and encourage the work of the various existing societies which are " engaged in promoting the study of mental disorders, the welfare of the insane, the problems of industrial psychology and the various aspects of mental deficiency "; it will also aim at establishing psychological clinics in general hospitals for the early treatment of mental disturbance, and at improving the education of the medical student in normal and abnormal psychology. In addition, it will attempt to lessen the popular ignorance at present prevailing in regard to the nature and prevention of mental illness, which results in an enormous amount of needless unhappiness and wastage of energy.

Such National Councils have been and are being formed in various countries on the Continent, moulded largely according to the pattern of the well-known United States National Committee for Mental Hygiene, which has done so much to raise the standard of the care and treatment of mental disorders in America, and to remove the widespread prejudice of the public towards these diseases. In America it has given birth to smaller Societies for Mental Hygiene in the various States and to an important Canadian Committee. Ample work awaits the formation of a National Council in Great Britain, and we extend to it the cordial welcome which it merits.

\section{University and Educational Intelligence.}

CAMBRIDGE.-The Report of the Financial Board on the expenditure of the current academic year points out that, despite the Emergency Grant of 30,0ool., the University depleted its balances by $3975 l$. during the past academic year; and it is anticipated that there will be a further deficit of $7650 l$. in the current year. The Report of the Royal Commission has not come any too soon unless Cambridge is to increase its fees or to cut down its activities.

Mr. H. G. Carter has been appointed Curator of the Herbarium.

The Linacre Lecture will be delivered on Saturday, May 6, at 5.I 5 P.M., by Sir Humphry Rolleston, on the subject of "Medical Aspects of Old Age."

London.- The following are among the Public Lectures to be given at University College during the present term :- "Atoms, Molecules and Chemistry," three lectures by Sir J. J. Thomson; "Insects and Disease," four lectures by Sir Arthur Shipley;

"Recent Discoveries in Egypt," by Prof, Flinders
Petrie; and "The Expansion of European Civilisation," four lectures, by Prof. W. R. Shepherd, of Columbia University. A copy of the full programme may be obtained by sending a stamped addressed envelope to the Secretary, University College, London, W.C.I.

IT is announced by the Royal Academy of Belgium that a prize of rooo francs has been established, which will be awarded biennially, under the name of the Prix O. van Ertborn, for the best work on geology.

Prof. E. Mellanby will deliver the Oliver Sharpey lectures at the Royal College of Physicians of London on Tuesday, May 2, and Thursday, May 4, at 5 o'clock. The subject of the lectures will be "Some Common Defects of Diet and their Pathological Significance."

The Ramsay Memorial Trustees will, at the end of June, consider applications for two Ramsay Memorial Fellowships for chemical research. One of the Fellowships will be limited to candidates educated in Glasgow. The value of the Fellowships will be $25 \mathrm{ol}$. per annum, to which may be added a grant for expenses not exceeding $50 l$. per annum. Full particulars as to the conditions of the award are obtainable from Dr. Walter W. Seton, Secretary, Ramsay Memorial Fellowships Trust, University College, London, W.C.I.

NEW regulations have recently been made by the Trustees of the Beit Memorial Fellowships for Medical Research. The date of the election of Fellows has been changed from December to July, so that Fellows may commence work on October $\mathrm{I}$, instead of January $\mathrm{I}$, in each year. In future there will be three classes of fellowships, namely, (I) junior fellowships, $35 \mathrm{ol}$. per annum. Not more than six junior fellowships will be awarded annually. The usual tenure of a junior fellowship is for three years. (2) Fourth-year fellowships, $400 \mathrm{l}$. per annum. On the recommendation of the advisory board, a junior fellowship may be extended for a further period of one year. (3) Senior fellowships, $600 l$. per annum. A limited number of senior fellowships may be awarded. The usual tenure of a senior fellowship is for three years. No change will be made in the emolument of any fellowship held at the date of coming into force of these amended regulations on May I, I.922. All correspondence of candidates and fellows should be addressed to the Hon. Secretary, Beit Memorial Fellowships, 35 Clarges Street, Piccadilly, W.r.

THE annual report for the session $1920-21$ of University College, London, contains some interesting facts which may well be placed on record. The total number of students enrolled for full time courses was 2408 , of which 1506 were men; in addition there were more than 700 attending part time courses. In the full time courses, arts and science claim about equal numbers. During the year, donations to the College amounted to a little more than $3000 l$., a total which includes sums of $\mathrm{I}_{5} \mathrm{Oo} /$. from the Carnegie United Kingdom Trust for the school of librarianship; $500 l$. from the Worshipful Company of Drapers, an annual grant to the biometric laboratory which will continue until 1924; and a grant of $250 l$. from the Chadwick Trustees for the departments of municipal engineering and hygiene. The London County Council made a capital grant of $5000 l$. towards the cost of the completion and equipment of the department of engineering. As in past years, the College has taken an active share in the promotion of adult education by the provision of free public lectures by men of note. In all, some seventy lectures and courses were given and it is estimated that more than 8000 persons attended.

NO. 2739 , VOL. IO9] 